\title{
GC-MS analysis of antibacterial compounds from floral part of methanolic extract of Rosa damascene
}

Saima Maher ${ }^{1 *}$, Iqra Anam ${ }^{1}$, Nadra Naheed ${ }^{2}$, Suad Naheed ${ }^{3}$, Saleha Suleman Khan ${ }^{1}$, Najeeb ullah ${ }^{4}$, Shazia Iqbal ${ }^{1}$ and Noureen Khan ${ }^{1}$

1. Department of Chemistry, Sardar Bahadur Khan Women University, Quetta, Balochistan-Pakistan

2. Department of Chemistry, Federal Urdu University of Science and Technology, Karachi-Pakistan

3. Department of Biochemistry, Jinnah University for Women, Karachi, Sindh-Pakistan

4. Director of Resurge Institute. Quetta, Balochistan-Pakistan

*Corresponding author's email: Saimamaher@yahoo.com

Citation

Saima Maher, Iqra Anam, Nadra Naheed, Suad Naheed, Saleha Suleman Khan, Najeeb ullah, Shazia Iqbal and Noureen Khan. GC-MS analysis of antibacterial compounds from floral part of methanolic extract of Rosa damascene. Pure and Applied Biology. Vol. 8, Issue 1, pp479-488. http://dx.doi.org/10.19045/bspab.2018.700206

\begin{tabular}{llll}
\hline \hline Received: 15/09/2018 & Revised: 05/12/2018 & Accepted: 07/12/2018 & Online First: 12/12/2018 \\
\hline
\end{tabular}

\section{Abstract}

The present study was carried out with the aim to evaluate the bioactive constituent in Rosa damascena, which is commonly called Demask rose, medicinal plant with biological significance and belongs to Rosaceae. The analyses were performed in methanolic extract with two fraction, Butanol and ethyl acetate. The analysis reveals presence of 09 bioactive compounds. Out of nine compounds, five were derivatives of methyl ester. Chemical compounds found in selected plants possess anti-oxidant potential which indicate potential against cancer disease. Plant also contains biological potential against microbes such as bacteria. Methanolic extract of plant in butanol and ethyl acetate fraction are found to possess significant potential to kill different bacterial species such as Pseudomonas aeruginosa, Klebsiella pneumoniae, Escherichia coli, and Proteus mirabillis. All these bacterial species were isolated from different sources such as pus, urine, vaginal sweat and sputum. Extract of Rosa damascena was able to kill all above mentioned species but was not capable to destroy Klebsiella oxytoca isolated from urine.

Keywords: Bioactive compounds; GC-MS hyphenated technique; in-vitro Antibacterial assay; Medicinal plants; Rosa damascena

\section{Introduction}

Resistance potential of bacteria against developed antibiotics given arise to the need for synthesizing new agent with anti-bacterial property as pathogenic bacteria are responsible for eruption of many diseases [1]. Bacterial strain and their resistance has forced researcher to search for new and active antimicrobial substance in nature which can be utilized as chemotherapeutic agent [2]. Many plants with medicinal characteristics can be used as antibacterial agent. One of such plant is Rosa damascena which belongs to Rosaceae family. The plant is commonly known as Demask rose [3]. The members of Rosaceae family are called king of flowers and have ornamental uses. Rosa damascena is among those species which have many 
significance in different aspects such as in rose oil and rose water production among all member of same family. The extract of Rosa damascena provides material for different daily used products belonging to cosmetic and perfume industry [4]. Reported therapeutic biological activities in this medicinally important species are antispasmodic [5], analgesic [6], Antioxidant [7], antiradical activity [8] and anti-HIV potential [9] Isolated compounds from Rosa damascena have been analyzed for potential against bacterial diseases $[10,11]$.

Hyphenated GC-MS technique is significantly helpful for analysis of any plant extract is with purpose for identification of active components responsible for specific character of biological activities of medicinal plant. It is hyphenated techniques which is helpful for identification of each component in mixture. It is done by comparison of spectra obtained by GC-MS instrument by reference spectra available in digital library [12].

\section{Materials and methods}

\section{Collection and identification of plant}

Flower of Rosa damascena was collected in June 2017 from district Quetta, Province Balochistan, Pakistan. Plant sample was deposited in Department of botany in SBKWU. Petals of collected samples were isolated and washed with distilled water. Clean samples were shade dried followed by grinding until fine powder was obtained.

\section{Extract preparation/sample preparation}

$150 \mathrm{~g}$ of dried powder of petals were soaked in methanol $80 \%$ pure solvent for 3 days. After this period the mixture was filtered. The filtrate obtained was evaporated till crude gummy material was obtained. This gummy extract was fractionated with hexane $(1000 \mathrm{ml})$, ethyl acetate $(50 \mathrm{~g})$ and butanol $(80 \mathrm{~g})$. The prepared samples were coded mentioned in (Table 1).

Table 1. Plant extract with code

\begin{tabular}{|c|c|}
\hline Plant extract code & Explanation \\
\hline R.D But & Rosa damascena extract in butanol \\
\hline R.D Ethyl acet. & Rosa damascena extract in ethyl acetate \\
\hline
\end{tabular}

\section{GC-MS analysis}

GC/MS was performed with model 'Agilent GC-MS triple quad 7000 GC 7890A'. Helium was utilized as carrier gas. Flow rate of carrier gas was $1.2 \mathrm{ml} / \mathrm{min}$. Analysis was made in spilt mode. Column dimension was $30 \mathrm{~m} \times 250 \mu \mathrm{m} \times 0.25 \mu \mathrm{m}$. Sample utilized during analysis was $3 \mu \mathrm{L}$. Temperature during analysis was $250{ }^{\circ} \mathrm{C}$ (source) and 350 ${ }^{0} \mathrm{C}$ (column) while oven temperature was maintained at $40{ }^{0} \mathrm{C}$. Total run time of analysis was 91.25 mins. Ionization technique utilized in this research was electron impact (EI) while detector used in GC-MS instruments was triple quadrapole. GC-MS library was also available for comparison of spectra with purpose of identification.

\section{Results and discussion}

Development of new drugs is need of this time. Medicinal plants are best source for medicinal purpose. The drugs obtained from natural source have encounter less side effects. Phytochemical isolated from plants have many biological potentials. Thus, these constituent may be directly and indirectly incorporated for synthesis of medicines. The present study was made in order to evaluate bioactive component of Rosa damascena by using GC-MS technique. Detailed information with respect of retention time (RT), Molecular formula (MF), molecular weight (MW), peak area are given in (Table 2). The GC chromatogram is shown in (Figurer 1). All peaks obtained were integrated and then, compared with data base 
for identification of compound. Data obtained from present research showed presence of 9 bioactive compounds (Table 3 ). All compounds were detected in hexane fraction of methanolic extract. All identified compounds belong to terpenes, phyto-sterol, tocopherol, fatty acid and methyl ester classes of organic compounds (Figure 2-10). Amongst identified phytochemical from Rosa damascena, $\alpha$-Amyrin, phytosterol and tocopherol compounds [13-15] have antioxidant potential. Vitamin $\mathrm{E}$ has also been found to exhibit anti-oxidant potential [16].
Ester compound are capable of scavenging free radicals. Detected compound $\alpha$-Amyrin possesses anti-depression potential as well [17]. Phyto-phenols are found to be health promoting substance [18]. Five methyl ester compounds have been detected during study. Many commercial applications have been associated with ester compounds [19]. Presence of above mentioned compounds belonging to some useful organic compounds classes in methanolic extract of Rosa damascena indicates its medicinal significance.

Table 2. GC/MS analysis of hexane extract of Rosa damascena

\begin{tabular}{|c|c|c|c|c|c|}
\hline S\# & R-T min & Compound name & Peak area & Molecular weight & Formula \\
\hline 1 & 63.38 & $\alpha$-Amyrin & 4.79 & 426 & $\mathrm{C}_{30} \mathrm{H}_{50} \mathrm{O}$ \\
\hline 2 & 62.60 & $\gamma$-Sitorol & 6.72 & 414 & $\mathrm{C}_{29} \mathrm{H}_{50} \mathrm{O}$ \\
\hline 3 & 59.38 & Vitamin E & 4.65 & 430 & $\mathrm{C}_{29} \mathrm{H}_{50} \mathrm{O}_{2}$ \\
\hline 4 & 52.00 & Docosanoic acid, methyl ester & 1.37 & 354 & $\mathrm{C}_{23} \mathrm{H}_{46} \mathrm{O}_{2}$ \\
\hline 5 & 23.42 & $\begin{array}{c}\text { 5-Acetoxy-2,6,6-trimethyl- } \\
\text { hept-3-enoic acid, methyl ester }\end{array}$ & 1.28 & 242 & $\mathrm{C}_{13} \mathrm{H}_{22} \mathrm{O}_{4}$ \\
\hline 6 & 20.91 & 3-Furanacetic acid & 9.51 & 240 & $\mathrm{C}_{12} \mathrm{H}_{16} \mathrm{O}_{5}$ \\
\hline 7 & 34.52 & $\begin{array}{c}9,12-\text {-octadecadienoic acid (Z- } \\
\text { Z),-methyl ester }\end{array}$ & 60.99 & 294 & $\mathrm{C}_{19} \mathrm{H}_{34} \mathrm{O}_{2}$ \\
\hline 8 & 29.98 & n-Hexadecanoic acid & 67.06 & 256 & $\mathrm{C}_{16} \mathrm{H}_{32} \mathrm{O}_{2}$ \\
\hline 9 & 28.39 & $\begin{array}{c}\text { Hexadecanoic acid, methyl } \\
\text { ester }\end{array}$ & 97.02 & 270 & $\mathrm{C}_{17} \mathrm{H}_{34} \mathrm{O}_{2}$ \\
\hline
\end{tabular}

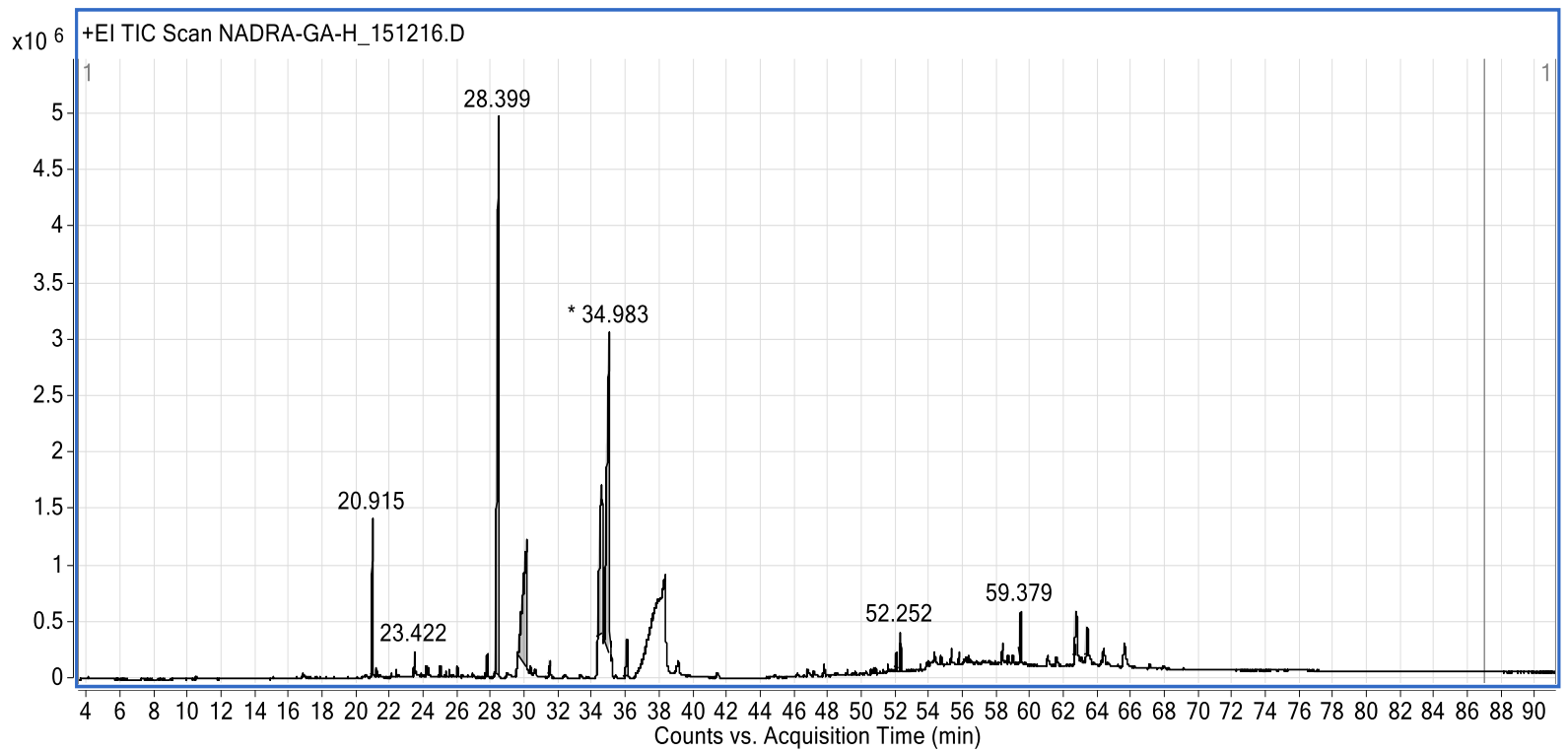

Figure 1. GC Chromatogram of hexane extract of plant 


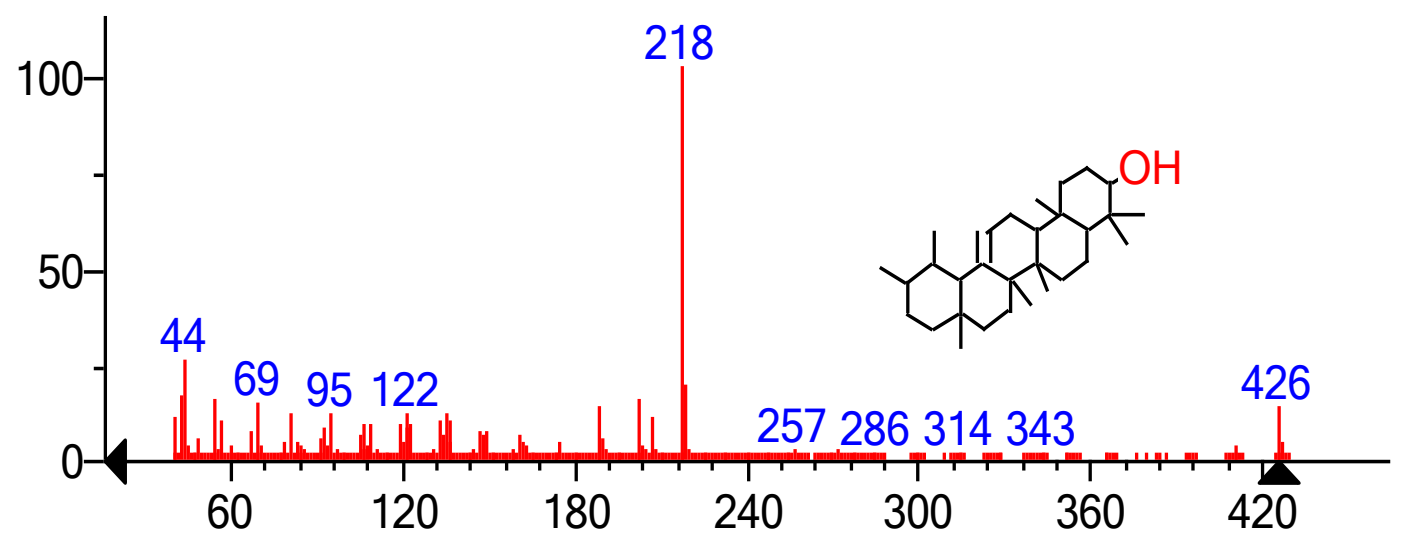

(replib) a-Amyrin

Figure 2. Spectra of $\alpha$-Amyrin

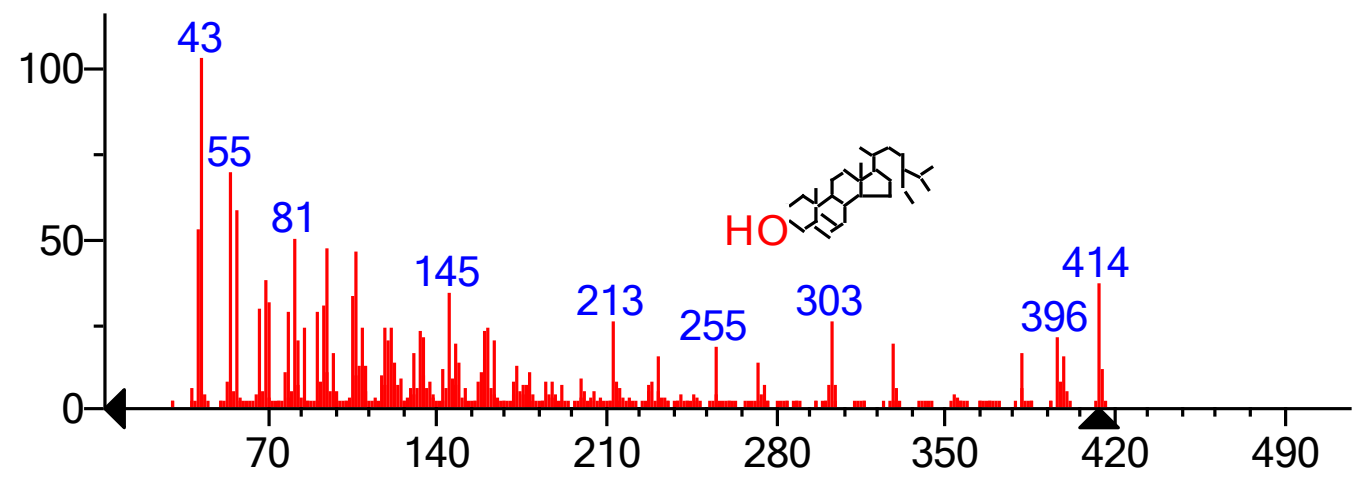

(mainlib) $y$-Sitosterol

Figure 3. Spectra of $\gamma$-Sitosterol

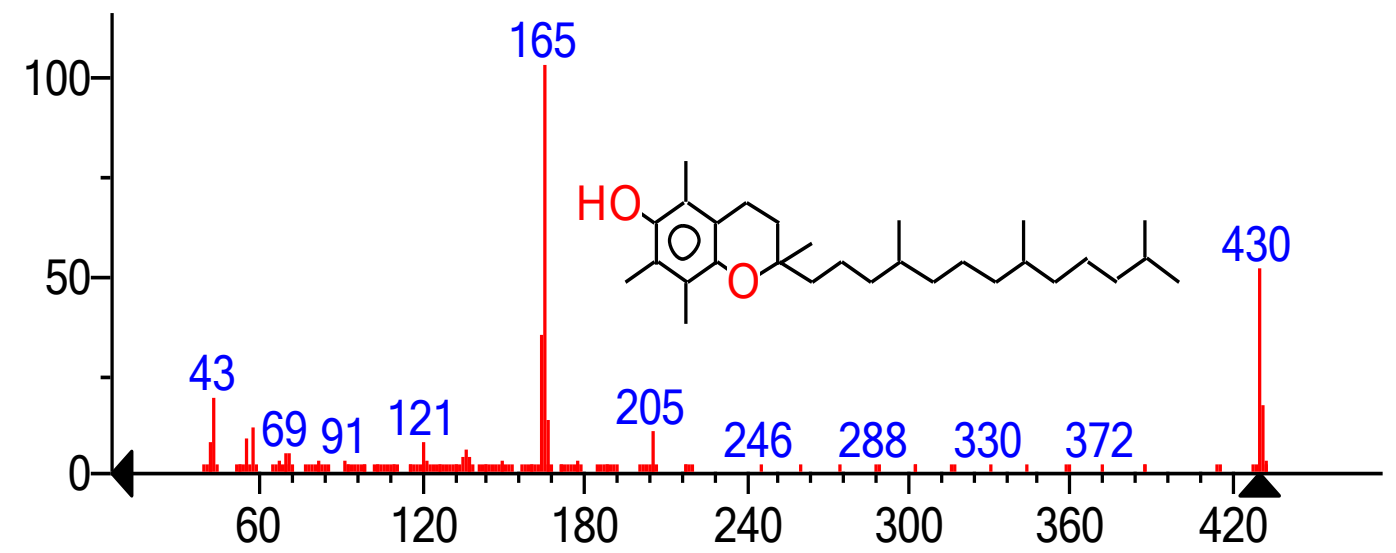

(replib) Vitamin E

Figure 4. Spectra of Vitamin E 


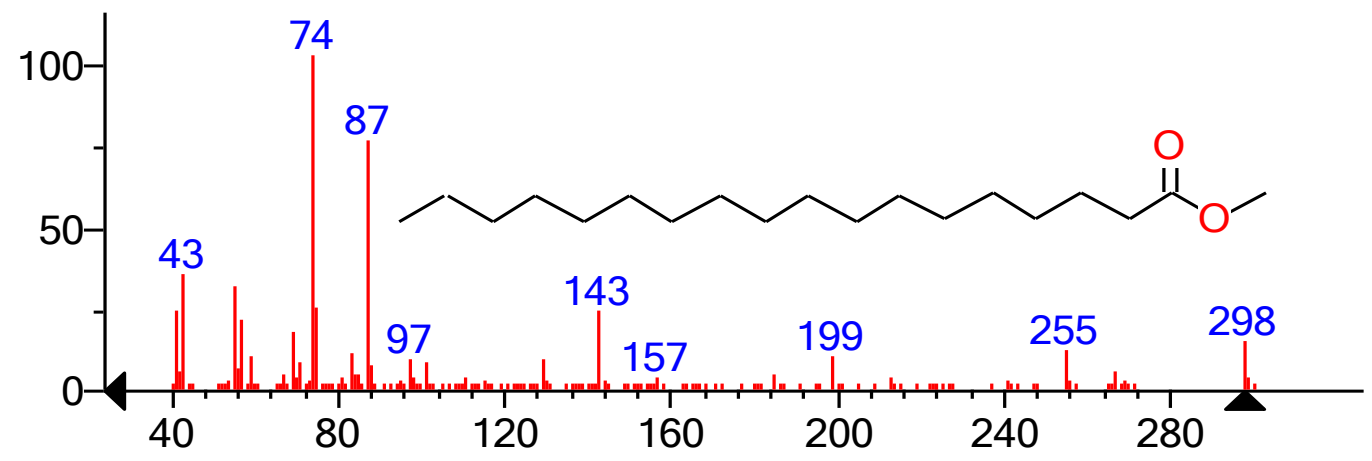

(mainlib) Octadecanoic acid, methyl ester

Figure 5. Spectra of Octa Decanoic Acid Methyl ester

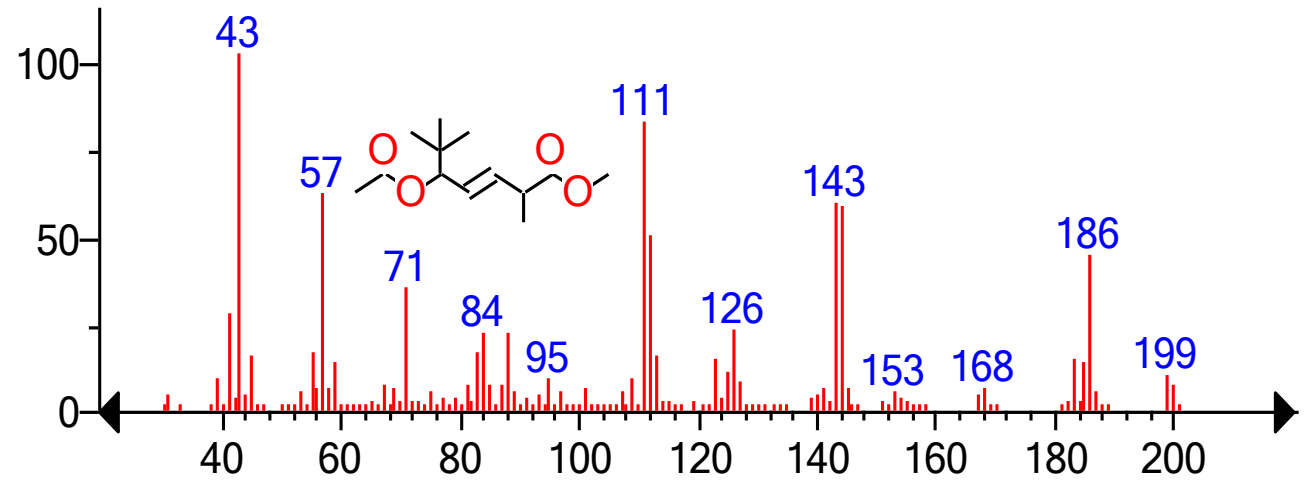

(mainlib) 5-Acetoxy-2,6,6-trimethyl-hept-3-enoic acid, methyl ester

Figure 6. Spectra of 5-Acetoxy-2,6,6-trimethyl-hept-3-enoic acid, methyl ester

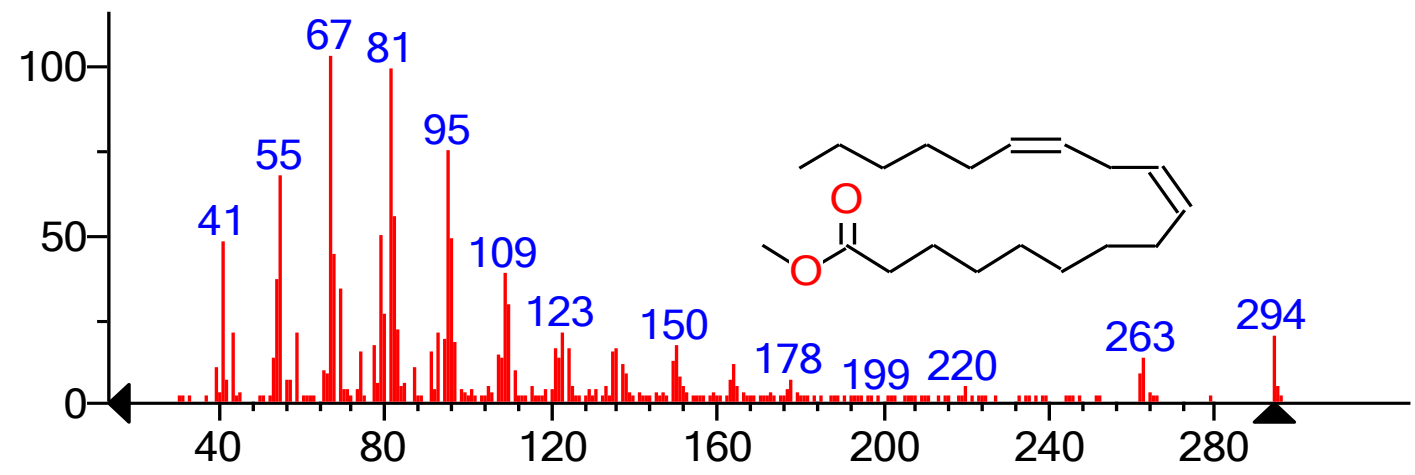

(mainlib) 9,12-Octadecadienoic acid (Z,Z)-, methyl ester

Figure 7. Spectra of 9, 12-octadecadienoic acid (Z-Z)-methyl ester 


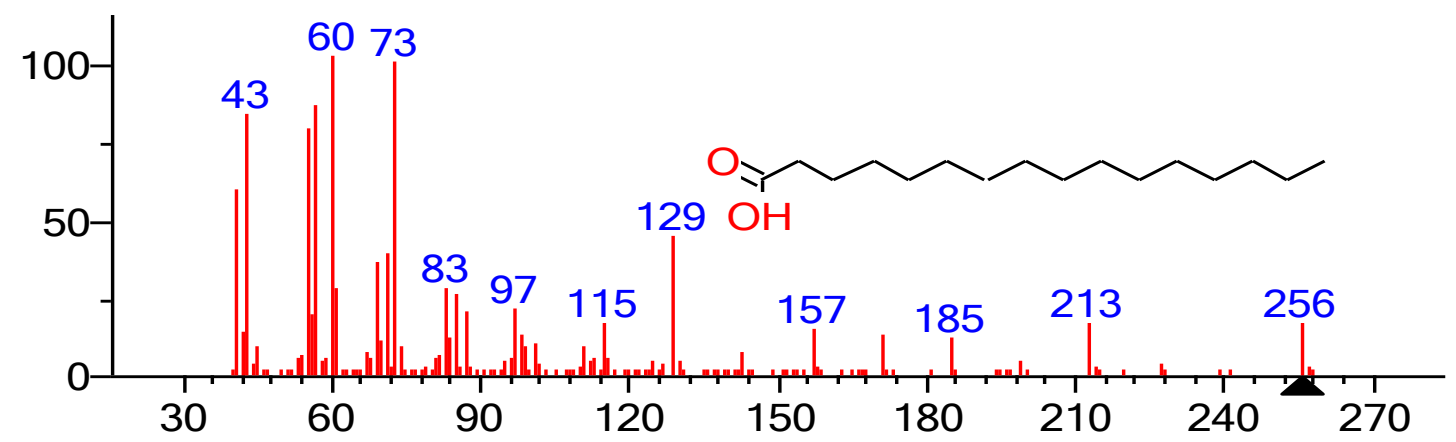

(replib) n-Hexadecanoic acid

\section{Figure 8. Spectra of n-Hexadecanoic acid}

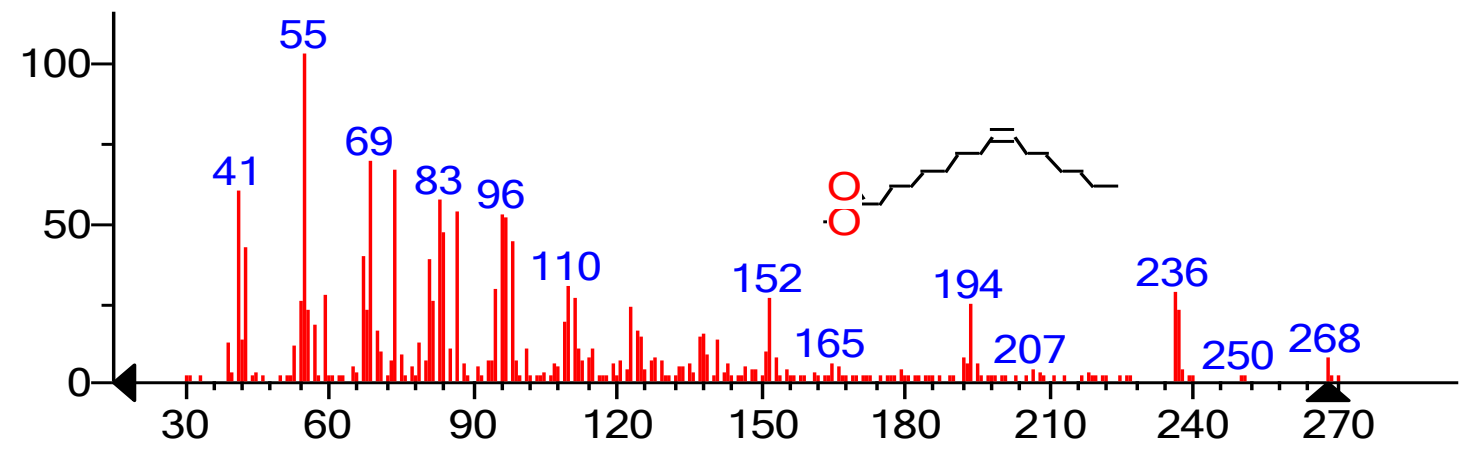

(mainlib) 9-Hexadecenoic acid, methyl ester, (Z)-

Figure 9. Spectra of 9- Hexadecanoic acid, methyl ester

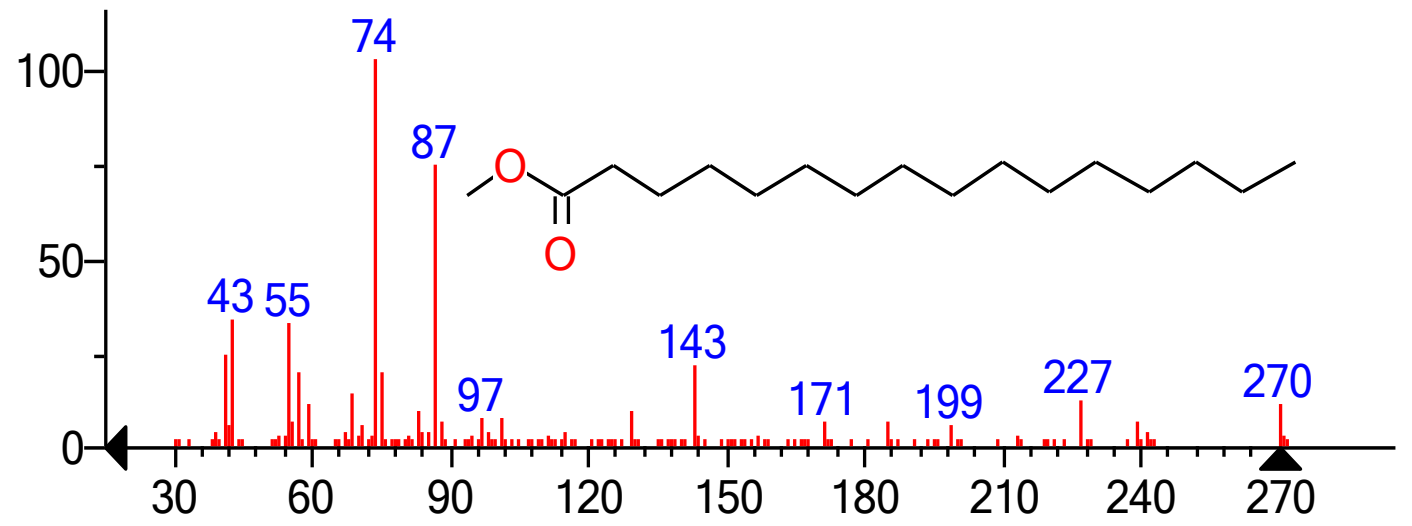

(mainlib) Hexadecanoic acid, methyl ester

Figure 10. Spectra of hexadecanoic acid, methyl ester

\section{Antibacterial assay}

Antibacterial activity of petals extract in ethyl acetate and butanol fraction was perform at Pharmacy lab, Jinnah University for Women, Karachi. Analysis was made by well diffusion method based on protocol defined by Uddin et al. [1]. The analyses were made on against Klebsiella pneumoniae, Pseudomonas aeruginosa, Escherichia coli, and Proteus mirabillis. These bacterial strains were isolated from pus, urine, vaginal sweat, Herpes Simplex 
Viral infection. All bacterial organisms were identified from the diagnostic Agha Khan laboratory, Karachi.

All isolated bacterial were cultured in presence of required nutrients for incubation period of 4 hours at $37^{\circ} \mathrm{C}$. The culture obtained was transferred to ager plants separately. For analysis distilled water was used as negative control. For each cultured stain, plant extract was examined. The shrinkage in culture loop of bacterial strain reflects positive potential of plant against that bacterial strain. Potential of Rosa damascena against bacterial strain is mentioned in (Table 4).

Table 3. Compound name with structure

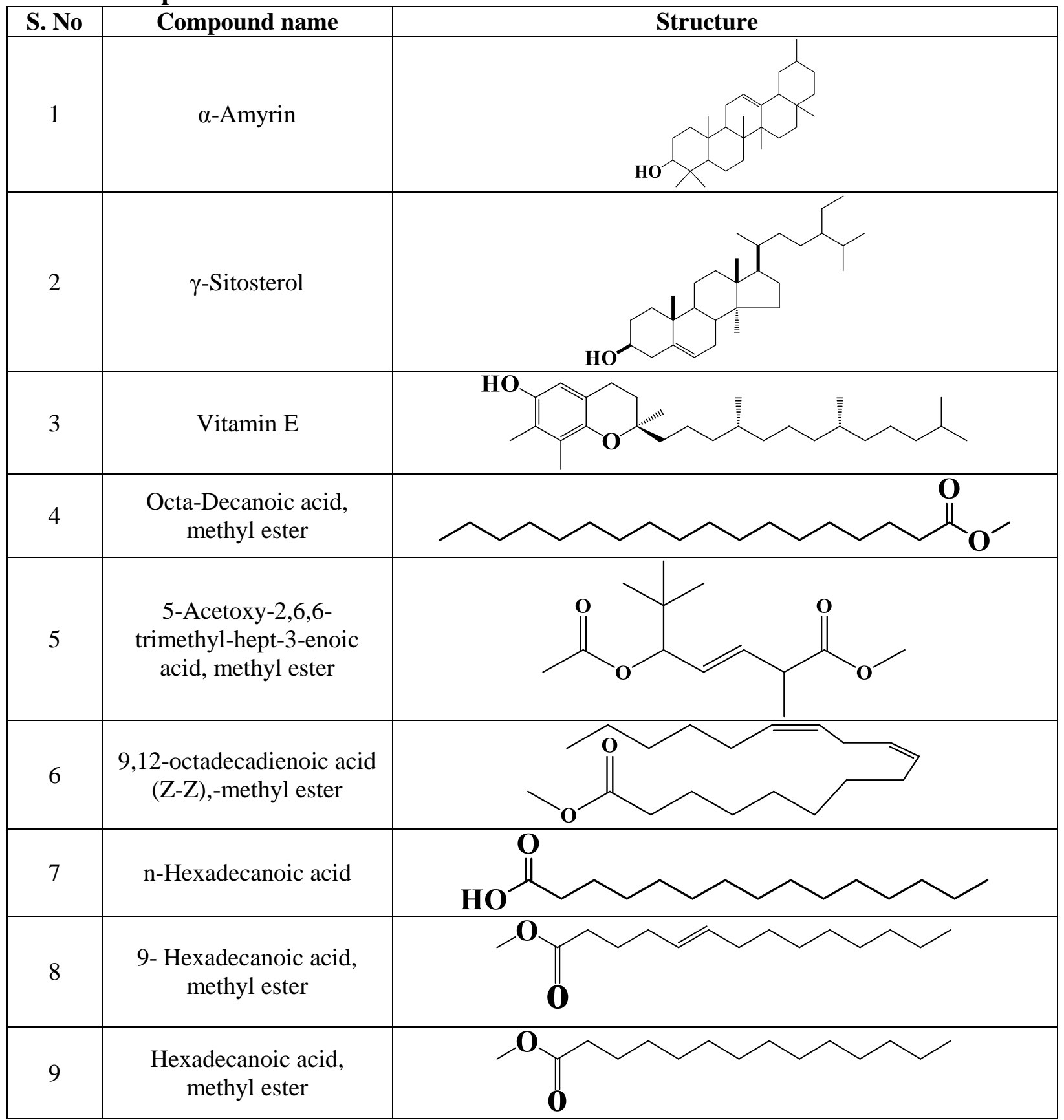


Table 4. Anti-bacterial analysis of extract obtained from petal of plant

\begin{tabular}{|c|c|c|c|}
\hline Organism & Source & $\begin{array}{c}\text { R.D* But. } \\
\text { 200mg/L } \\
\text { ZOI }(\mathbf{m m}) \pm \text { SEM })\end{array}$ & $\begin{array}{c}\text { R.D* eth. Acet. } \\
200 \mathrm{mg} / \mathrm{L} \\
\text { ZOI }(\mathrm{mm}) \pm \text { SEM }\end{array}$ \\
\hline Klebsiella pneumoniae & Sputum & Nil & Nil \\
\hline Pseudomonas aeruginosa & Pus & Nil & $19.6 \pm 2.7284$ \\
\hline Klebsiella pneumoniae & Urine & $18 \pm 0.577$ & $19 \pm 0.5773$ \\
\hline Klebsiella pneumoniae & Vaginal sweat & Nil & $16.6 \pm 0.6666$ \\
\hline Proteus mirabillis & Urine & $10 \pm 0.5773$ & Nil \\
\hline Escherichia coli & Urine & $17 \pm 0.57$ & $19.33 \pm 0.66$ \\
\hline Proteus mirabillis & Urine & Nil & $9 \pm 0.57$ \\
\hline Klebsiella pneumoniae & Urine & Nil & $13.66 \pm 0.33$ \\
\hline Escherichia coli & $\begin{array}{l}\text { Herpes Simplex } \\
\text { Viral infection }\end{array}$ & Nil & $12.33 \pm 0.33$ \\
\hline Escherichia coli,+ proteus & Urine & $8 \pm 0.57$ & $17 \pm 1.52$ \\
\hline Klebsiella pneumoniae & Pus & $9 \pm 0.57$ & Nil \\
\hline Klebsiella oxytoca & Pus ear & Nil & $12.63 \pm 0.33$ \\
\hline Klebsiella pneumoniae & Pus & Nil & Nil \\
\hline Proteus mirabillis & Urine & $7.33 \pm 0.33$ & \\
\hline Escherichia coli & Urine & $12.66 \pm 0.33$ & $10.66 \pm 0.33$ \\
\hline Klebsiella oxytoca & Urine & Nil & Nil \\
\hline Pseudomonas aeruginosa & Urine & $10.33 \pm 0.33$ & Nil \\
\hline Klebsiella + Candida specie & Urine & Nil & $17 \pm 0.57$ \\
\hline
\end{tabular}

*Rosa damascena

Potential of Rosa damascena against bacterial strain is mention in (Table 4). In comparison of butanol and ethyl acetate fraction of Rosa damascena medicinal plant, ethyl acetate fraction was effective and showed good efficiency against maximum bacterial species. Values greater than $11 \mathrm{~mm}$ reflect good potential of plant against under observed bacterial species. Values in the range of 16-19 reflect best antibacterial potential. Highest activity was observed with Pseudomonas aeruginosa. $200 \mathrm{mg}$ of ethyl acetate fraction was enough to show higher zone of inhibition which reflects plant's good potential as antibacterial agent. In butanolic fraction best activity was observed against Klebsiella pneumoniae and Escherichia coli while satisfactory activity was observed against Proteus mirabillis, Pseudomonas aeruginosa and Escherichia coli. All these were isolated from urine source. No activity was observed against bacterial isolated from all other sources. Observation on ethyl acetate fraction reveals great efficacy of plants against maximum bacterial spices except Proteus mirabillis. Plant was much more effective against Escherichia coli, Klebsiella pneumoniae and Pseudomonas aeruginosa with maximum zone of inhibition. Plant extract against in both fractions showed no potential to fight against Klebsiella oxytoca (isolated from urine), Klebsiella pneumoniae (isolated from sputum, pus).

\section{Conclusions}

Medicinal plants are considered backbone for traditional treatments. Rosa damascena is also medicinal plant which is analyzed in present work. Research was made to find out active component by GC and to evaluate the biological potential through bacterial analysis. In the hexane extract of this plant nine active compounds were detected. Plant was observed with significance potential against bacterial strain. 


\section{Author's contributions}

Experimental design: $\mathrm{S}$ Maher, Sample collection: I Anam \& N Ullah, Extract preparation, S Maher, S Suleman \& I Anam, Culture preparation: S Maher \& I Anam, GC.MS analysis: N Naheed, Antibacterial analysis: S Naheed, GC-MS Data analysis: S Maher, I anam \& S Suleman, Antibacterial data analysis: I anam, S Iqbal, N Khan \& S Naheed, Wrote the paper: I Anam, N Ullah, Paper refining and checking: S Maher, I anam \& S Suleman.

\section{References}

1. Uddin B, Hossan T, Paul S, Ahmed T, Nahar T \& Ahmed S (2010). Antibacterial activity of the ethanol extracts of Hibiscus rosa-sinensis leaves and flowers against clinical isolates of bacteria. Bangladesh J Life Sci 22(2): 65-73

2. Barbour KE, Al Sharif M, Sagherian VK, Habre AN, Talhouk RS \& Talhouk SN (2004). Screening of selected indigenous plants of Lebanon for antimicrobial activity. Journal of Ethno Pharmacol 93(1): 1-7.

3. Kaul VK, Virendra $\mathrm{S}$ \& Bikram $\mathrm{S}$ (2000). Damask rose and marigold: prospective industrial crops. J of Med and Aromatic Plant Sci 22(1B): 313318.

4. Aycı F, Aydınlı M. Bozdemir OA \& Tutaş M (2005). Gas chromatographic investigation of rose concrete, absolute and solid residue. Flavor and Frag J 20(5): 481-486.

5. Libster M. (2002). Delmar's integrative herb guide for nurses. Delmar/Thomson Learning. 360-370.

6. Basim E \& Basim H (2003). Antibacterial activity of Rosa damascena essential oil. Fitoterapia 74(4): 394-396

7. Yassa N, Masoomi N. Rankouhi SR, \& Hadjiakhoondi A (2015). Chemical composition and antioxidant activity of the extract and essential oil of Rosa damascena from Iran, population of Guilan, DARU. J of Pharma Sci 17(3): 175.

8. Baydar NG \& Baydar H (2013). Phenolic compounds, antiradical activity and antioxidant capacity of oil-bearing rose (Rosa damascena Mill.) extracts. Indus Crops and Products 41: 375-380.

9. Mahmood N, Piacente S, Pizza C, Burke A, Khan AI \& Hay AJ (1996). The AntiHIV Activity and Mechanisms of Action of Pure Compounds Isolated from Rosa damascena. Biochem and Biophy Res Commun 229(1): 73-79.

10. Özkan G, Sagdic O, Baydar NG \& Baydar H (2004). Antioxidant and antibacterial activities of Rosa damascena flower extracts. Revista de Agaroquimica y Tecnologia de Alimentos 10(4): 277-281.

11. Achuthan CR, Babu BH \& Padikkala J (2003). Antioxidant and hepatoprotective effects of Rosa damascena. Pharma Biol 41(5): 357361.

12. Hites RA (1997). Gas chromatography mass spectrometry. Handbook of instrumental techniques for analytical chemistry 609-626.

13. Singh D, Arya PV, Sharma A, Dobhal MP \& Gupta RS (2015). Modulatory potential of $\alpha$-amyrin against hepatic oxidative stress through antioxidant status in wistar albino rats. $J$ of Ethnopharmacol 161: 186-193

14. Wang T, Hicks KB \& Moreau R (2002). Antioxidant activity of phytosterols, oryzanol, and other phytosterol conjugates. $J$ of the American Oil Chem Soc 79(12): 1201-1206.

15. Kamal-Eldin A \& Appelqvist LA (1996). The chemistry and antioxidant properties of tocopherols and tocotrienols. Lipids 31(7): 671-701. 
16. Tappel AL (1962). Vitamin E as the biological lipid antioxidant. Vitamins \& Hormones 20: 493-510

17. Aragão GF, Carneiro LMV, Junior APP, Vieira LC, Bandeira PN, Lemos TLJ \& Viana JDB (2006). A possible mechanism for anxiolytic and antidepressant effects of alpha-and beta amyrin from Protium heptaphyllum (Aubl.) March. Pharmacol Biochem and Behavior 85(4): 827-834.

18. Machado TB, Pinto AV, Pinto MCFR, Leal ICR, Silva MG \& Amaral ACF,
Netto-dosSantos KR (2003). In vitro activity of Brazilian medicinal plants, naturally occurring naphthoquinones and their analogues, against methicillinresistant Staphylococcus aureus. Intern J of Antimicrobial Agents 21(3): 279-284.

19. Foresti ML, Errazu A \& Ferreira ML (2005). Effect of several reaction parameters in the solvent-free ethyl oleate synthesis using Candida rugosa lipase immobilised on polypropylene. Biochem Engi J 25(1): 69-77. 